氏に深く感㩱する。（昭和 31 年 4 月笴穆）

$$
\text { 文 献 }
$$

1) J. L. Wyatt: J. Metals, 2 (1950) 989

2) J. L. Wyatt: J. Metals, 2 (1950) 1382

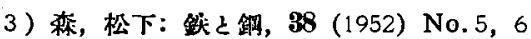

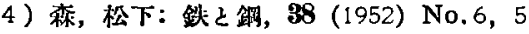

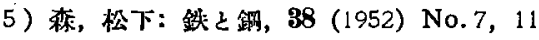

6) 森, 松下: 鉄之唡, 38 (1952) No.8, 15

7) G. Heidtkamp, K. Endell: Glastech. Ber., 14 (1936) 80

8) K. Endell, H. Hellbrügge: Angew. Chem., 53 (1940) 271

9) J. O'M. Bockris, J. A. Kitchner, S. Ignatowicz and J. W. Tomlinson: Trans. Farad Soc., 48 (1952) 75

10) A. Chrétien et W. Freundlich:Compt. rend.,
283 (1951) 413

11) W. Schaller: Z. Erz. Metall. 7 (1954) 18

12）武井：電気化学, 23 (1955) 433

13) K. H. Sun: Glass Ind., 29 (1948) 73

14) J. O'M. Bockris, J. A. Kitchner, S. Ignatowicz and J. W. Tomlinson: Dicuss. Farad Soc., (1948) 4, 265

15) K. Endell und G. Brinkmann: Stahl und Eisen, 59 (1939) 1319

16) P. Kozakevitch: Rev. Mét., 46 (1949) 572

17) M. G. Urbain: Compt. rend., 232 (1951) 330

18) A. M: Chernyshev, L. M. Tsylev i A. V. Rudneva: Izvest. Akad. Nauk SSSR, Qtdel. Tekh. Nauk, (1953) No.7, 1044

\title{
熔鋼中の水素に関する研究 $(\mathrm{III})^{*}$ \\ (鋼洋含有水素の定量について)
}

\author{
沢 \\ 繁 樹** \\ HYDROGEN IN MOLTEN STEEL (III)
}

(Analysis of Hydrogen in Steelmaking , Slag)

Shigeki Sawa. Dr. Eng.

Synopsis:

A study was made of vacuum heating method up to $1200^{\circ} \mathrm{C}$, and vacuum fusion method up: to $1800^{\circ} \mathrm{C}$ in a graphite or Mo crucible for determination of hydrogen content in steelmaking slag. To amalyse the gas extracted by vacuum fusion of the specimen; thermoconductivity method was applied, the accuracy of which was improved by means of new type thermoconductivity cells, made from thin $\mathrm{Cu}$ tubes dipped in ice water which was stirred by an impeller and separated from. contact with ice by a network. The following conclusions were reached:

1) Hydrogen in steelmaking slag could not be extracted completely by vacuum heating only up to $1200^{\circ} \mathrm{C}$ for complete extraction of hydrogen. It should be heated to above $1400^{\circ} \mathrm{C}$ or its melting point.

2) $\mathrm{H}_{2} \mathrm{O}$ in the specimen was quantitatively decomposed in the vacuum furnace and extracted as $\mathrm{H}_{2}$ when it was melted in a graphite crucible. This fact was confirmed by extracting $\mathrm{H}_{2}$ in minerals such as gypsum and actinolite.

3) Strong adsorption, of $\mathrm{H}_{2}$ caused by vaporization of reduced material of slag specimen in the vacuum furnace was found, when it was heated at high temperature in a graphite crucible. The effect was minimized, on the contrary, when a Mo crucible was used.

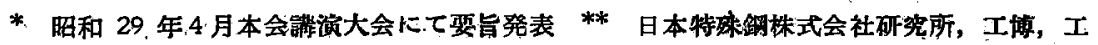


4) Vacuum fusion method with Mo crucible was made available for the purpose stated above.

\section{I. 粕一論}

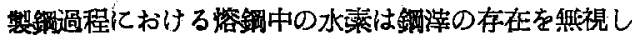
て侤えることができない. 第2 報りにお゙いて述べた裸の

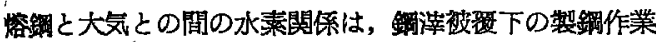
には成立しないととは第 1 報〉の実作業のデータより明

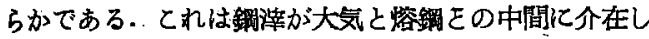
て，大気中の水蒸気あるいは熔鎆面の水素の運搬者の役 目を果し，大気，鋼慞，螾鋼間水素関す万定常状態

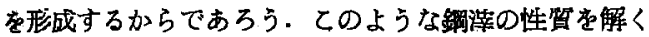
ためには，その水素含有豆を知る必要がある.

P. Herasymenko および P. Dombrowski ${ }^{3)}$ はと の分野の稀な研觉の一つを報告した：彼等は熄基性およ

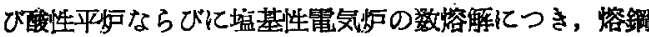
一鎆浑間の水素平衡を論じ，Mn が関保すると結論し た. 本邦においても小林氏がいち早くこの方面の研究 を進められた，従来行われた鋼愺含有水菜の定量洷はつ ぎの通りである。

1) 鋼涬を $\mathrm{O}_{2}$ 気流中 $800^{\circ} \mathrm{C}$ 加熱し生成する $\mathrm{H}_{2} \mathrm{O}$ を定荲する然焷法5)

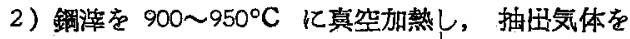
$700^{\circ} \mathrm{C}$ に加榇した Fe-Mn を通し生ずる $\mathrm{H}_{2}$ を定量す 方方法 ${ }^{3}$

3）鋢㴖を $1200^{\circ} \mathrm{C}$ 亿て真空加熱する小林氏の方沠" 燃愤洁による分析值は $24^{\circ} 9$ 9 208cc/100g， Herasy.

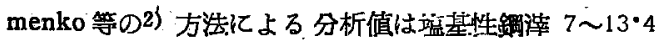

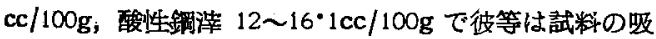
湿防止のため粒状の試料を用いた点に特色がある.小林 氏の得た值は站基性鍮滓に対し $\mathrm{H}_{2} 2 \cdot 5 \sim 13 \cdot 5 \mathrm{cc} / 100 \mathrm{~g}$,

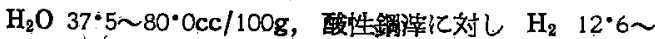
$21^{-4} \mathrm{cc} / 100 \mathrm{~g} ; \mathrm{H}_{2} \mathrm{O}$ 18・8〜45・0cc/100g であつた. H. Wentrup, H. Fucke および O. Rief は盐基性鋼㳯 汶し $\mathrm{H}_{2} 10 \sim 30 \mathrm{cc} / 100 \mathrm{~g}, \mathrm{H}_{2} \mathrm{O} 30 \sim 175 \mathrm{cc} / 100 \mathrm{~g}$, 酸

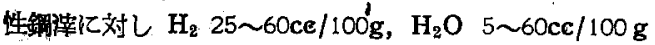
の值を提田したが分析法の詩細は不眀である.

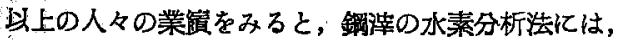
試料の播取法，探取した陚料の昨湿防止法，抽活温度， 等にそれぞれ特色があるが。上記分析值を相互に比較し

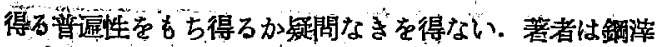

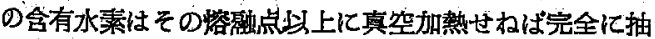

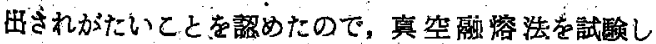
t.

\section{II. 鋼漳中の水素の抽出温度}

a ） $1200^{\circ} \mathrm{C}$ 以下の悬空加爇により発生する水素

Fig. 1 恃堸㴖を $1200^{\circ} \mathrm{C}$ 以下加熱して生成する $\mathrm{H}_{2} \mathrm{O}$ および $\mathrm{H}_{2}$ を定量する目的にて製作した装圆の略

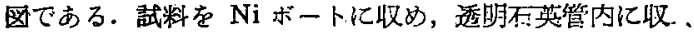
納して真空加熱する，水銀㹡散ポンプにより発生気体を 真空瓶内に蓄積し，その王を特殊の㯖空計 Jによつて测. 定する. J は McLeod 型ゲージ゙あるが水蒸気を含む

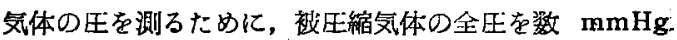

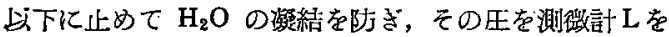
铎えた水銀マノメーターKによつて正確に測る。この方

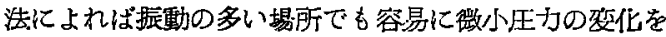
測定するととが可能である，つぎに気体を循還させて $\mathrm{P}_{2} \mathrm{O}_{5}$ により $\mathrm{H}_{2} \mathrm{O}$ を除去しふたたび測压して $\mathrm{H}_{2} \mathrm{O}$ を! 覓出し，残余の気体は水銀滴下ポンプにより描集して， Orsat 装置により分析した。
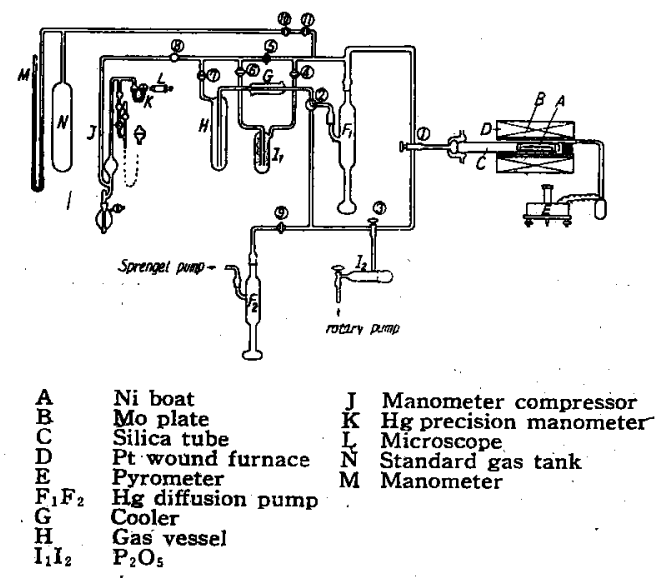

Fig. 1.' Apparatus for extracting hydrogen from steelmaking slag by vacuum heating up to $1200^{\circ} \mathrm{C}$.

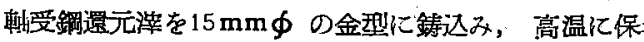
ちつつ試料が崩境する前に $\mathrm{Ni}$ ボートに収めて石英管に 入れて，排気する．徐々に加熱温度を高めつつ抽出気体 量およびその組成を調べると Fig. 2 のでとくである. すなわち $400^{\circ} \mathrm{O}$ 附近より $\mathrm{H}_{2} \mathrm{O}$ および $\mathrm{H}_{2}$ が発生し, $\mathrm{CO}_{2}$ は $400^{\circ} \mathrm{C}$ 上上加ら生し温度の上萃とともに増加す る. $\mathrm{CO}$ は $600^{\circ} \mathrm{C}$ を越して発生し, $950^{\circ} \mathrm{C}$ 以上より急 増する. $\mathrm{H}_{2}$ の発生は $1200^{\circ} \mathrm{C}$ までの真空加熱によつて なお停止する様子がなく；， $\mathrm{H}_{2}$ を完全に抽席するには一 


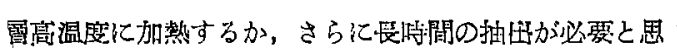
われる。

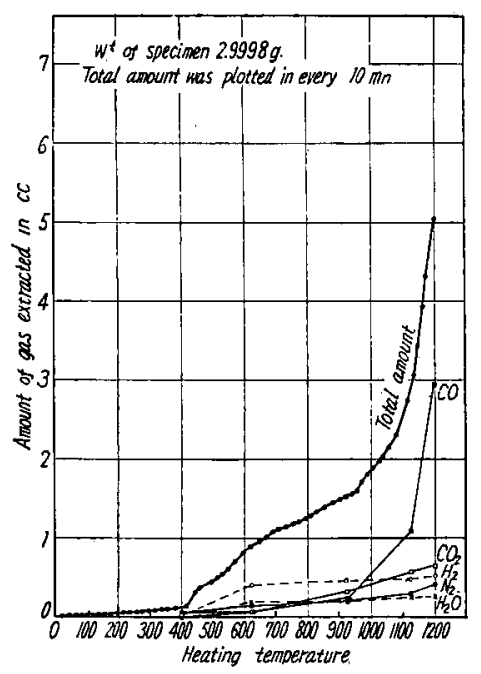

Fig. 2. Gas extracted from basic reducing slag by vaccum heating.

b）鎙の真空熔融装置に上る鋼㵏中の水素定量の可能 性

銅漳を $1200^{\circ} \mathrm{C}$ 以上に真空加熱するには夹際上かなり 困難施る。よつてきき報告した鋼の水素迅速定最装 置》を用い，試粼を黒鉛坩堝中にて真空熔融し，この際

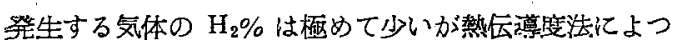
て精璴よく分析した。ただし CO の外䎲 $1 \%$ 内外の $\mathrm{CO}_{2}$ を伴うから， $\mathrm{KOH}$ によつて $\mathrm{CO}_{2}$ を除去して熱 伝拿度装睓に送つた。

鍓涬には $\mathrm{H}_{2} \mathrm{O}$ として抽出される成分を含むが，ての
ような条件で真空熔鞂すると； $\mathrm{H}_{2} \mathrm{O}$ は坩堝その他のC と反応して定量的に $\mathrm{H}_{2}$ として抽任される事がつるさ うに証明された。堸㵏類似の組成をるつ念水標淮試料と

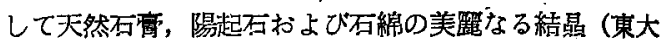

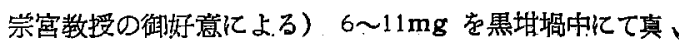
空熔墈した. $\left(1500 \sim 1850^{\circ} \mathrm{C}\right)$ その結果は Table 1 に 示すとおり，試料が小量のため若干の分析誤差は免れな いが，石育および陽起石より $\mathrm{H}_{2}$ として抽出された水素 は分子式より䑒算した理諭值と一致した．石綿は著しく 理諭傎と基なるが，灼熱減量より求めた $\mathrm{H}_{2} 0 \cdot 285 \%$.と

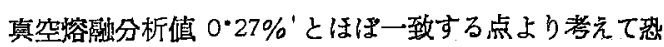
らく鉱物自体の組成力理論值と異なるものと考えられ

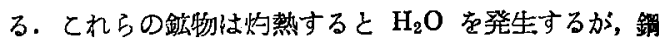
の真空撘副分析装置において試料より発生する $\mathrm{H}_{2} \mathrm{O}$ か 黒鈶と反応して定量的に $\mathrm{H}_{2}$ として抽出されることは注 目すべきである：とのことはさきにり触れて置いた处で ある・

c）真空少の温度降下による水素吸仪と再加熱による 放出特性の㭘討

鋼㴖中の水素の抽画温度を沃定するに当り，真空炣を 排気温度 $1800 \sim 1900^{\circ} \mathrm{C}$ 上り試験温度たとえば $1200^{\circ} \mathrm{C}$ まで降下させたとき，真空师が気体の吸請能をるち，試 料より発生した気体の一部を吸蔵し，绵温の上昇に伴つ てその一部が排出される現象はすでに指摘〉した処であ， る.もし $\mathrm{H}_{\mathrm{z}}$ 亿関して同様の現象があれば, 試料より発 生した $\mathrm{H}_{2}$ の一部が見排け上より高温度まで抽出されな いという誤つた結論を傅く恐れがある．との点を検討す るため真空师を $1850^{\circ} \mathrm{C}$ において長脚間排気し，炉温を $1000^{\circ} \mathrm{C}$ として Mond $\mathrm{Ni}$ 唗城内に投入する. Ni り発生する $\mathrm{H}_{2}$ を抽国し, 犵温を $100^{\circ} \mathrm{C}$ 宛階段的に上

Table 1. Analysis of hydrogen in several minerals including water of crystallization by vacuum fusion in graphite crucibles.

\begin{tabular}{l|c|c|c|c|c}
\hline Specimens & Molecular formula & $\begin{array}{c}\text { Theoretical } \\
\mathrm{H}_{2} \%\end{array}$ & $\begin{array}{l}\text { No. of ana- } \\
\text { lysis }\end{array}$ & $\begin{array}{l}\text { Mean } \mathrm{H}_{2} \% \\
\text { analysed }\end{array}$ & Range of $\mathrm{H}_{2} \%$ \\
\hline Gypsum & $\mathrm{CaSO}_{4} \cdot 2 \mathrm{H}_{2} \mathrm{O}$ & $2 \cdot 32$ & 6 & $2 \cdot 30$ & $2 \cdot 15 \sim 2 \cdot 47$ \\
Actinolite & $\mathrm{H}_{2} \mathrm{Ca}_{2} \mathrm{Mg}_{5} \mathrm{Si}_{8} \mathrm{O}_{24}$ & $0 \cdot 246$ & 5 & $0 \cdot 23$ & $0 \cdot 21 \sim 0.26$ \\
Crysotile & $\mathrm{H}_{4} \mathrm{Mg}_{3} \mathrm{Si}_{2} \mathrm{O}_{9}$ & $1 \cdot 44$ & 5 & $0 \cdot 27$ & $0 \cdot 23 \sim 0 \cdot 29$ \\
\hline
\end{tabular}

Table 2. $\mathrm{H}_{2}$ extracted from vacuum furnace during every $15 \mathrm{~min}$ at the indicated temp. which was elevated after Mond $\mathrm{Ni}$ specimen was dropped in the crucible at $1000^{\circ} \mathrm{C}$.

\begin{tabular}{|c|c|c|c|c|c|c|c|c|c|c|c|}
\hline Specimens & wt. $g$ & $1000^{\circ} \mathrm{C}$ & $1100^{\circ} \mathrm{C}$ & $1200^{\circ} \mathrm{C}$ & $1300^{\circ} \mathrm{C}$ & $1400^{\circ} \mathrm{C}$ & $1500^{\circ} \mathrm{C}$ & $1600^{\circ} \mathrm{C}$ & $1700^{\circ} \mathrm{C}$ & $1800^{\circ} \mathrm{C}$ & $\begin{array}{l}1900 \\
{ }^{\circ} \mathrm{C}\end{array}$ \\
\hline Mond $\mathrm{Ni}$ & $2 \cdot 40$ & $1 \cdot 32$ & $\cdot 005$ & $\cdot 004$ & $\cdot 007$ & .00 & .00 & 01 & .00 & $\therefore 04$ & .03 \\
\hline Ditto with $\mathrm{AI}$ & $3 \cdot 44$ & $2 \cdot 32$ & .029 & .022 & .046 & $\therefore 003$ & $\cdot 00$ & .00 & $\cdot 00$ & .014 & $\therefore 07$ \\
\hline
\end{tabular}


异させ，芼温度に $15 \mathrm{mn}$ 宛保持して発生する気体を抽 出し $\mathrm{H}_{2}$ を定量する.その結果は Table 2 のとおりて ある.

すなわち Mond Ni 単独の㹇合および Mond Ni を Al 䇴に包んだ惕合，何れも $1000^{\circ} \mathrm{C}$ において大部分の 合有 $\mathrm{H}_{2}$ か抽度される. Mond $\mathrm{Ni}$ は $1320^{\circ} \mathrm{C}$ 附近で熔

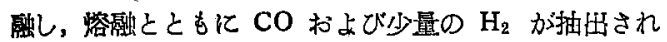
ろ. $1100 \sim 1300^{\circ} \mathrm{C}$ 閪に抽出される微量の $\mathrm{H}_{2}$ は Mond $\mathrm{Ni}$ 空洞部口分于状 $\mathrm{H}_{2}$ が稌々に抽四されるためであろ う. $1400 \sim 1700^{\circ} \mathrm{C}$ 間では真空师からあらたに $\mathrm{H}_{2}$ は抽 出されない. $1800 \sim 1900^{\circ} \mathrm{C}$ にて抽球される $\mathrm{H}_{2}$ は, 师 を長時間低温度に保つたために师内壁に附着してきたグ リースの影響および师温を最初の排気温㡺上上に高めた ためである。てれを要するに，1850 C 亿て排気した真 空炉を $1000^{\circ} \mathrm{C}$ とし, 炉内に多量の $\mathrm{H}_{2}$ を発生せしめた か，灯温を逐次上昇せしめても，1400 $1700^{\circ} \mathrm{C}$ 亿おい て师から $\mathrm{H}_{2}$ は発生しない. $1800 \sim 1900^{\circ} \mathrm{C}$ にて少量 $\mathbf{H}_{2}$ が登生するが, 次節の実験結果と対比して, 真空炬

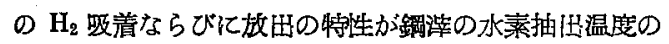
決定に障害を与えないと媤められる。

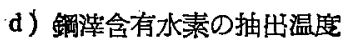

i) 盗基性酸化溹

塩基性酸化湳の粒 $905 \mathrm{mg}$ を䅘取し, $1150^{\circ} \mathrm{C}$ に保つ た黒鈶坩堝中に投入する.水素の発生がほとんど停止し たとき温㡲を上昇する.かかる操作を繰返し温度を次第
に上䒜させて $\mathrm{H}_{2}$ の発生状沅を調べた。 Table 3 はそ の絬果である.

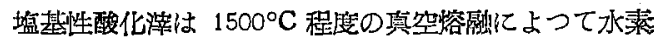

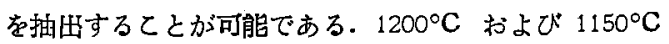
の索空加熱を通算 $200 \mathrm{mn}$ 行つているが，乙の間に抽出 された $\mathrm{H}_{2}$ は全量の $66^{\circ} 8 \%$ 亿過ぎな.

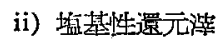

Cr-Mo 鋼の出鋼直前の鋼漟を試料として，抽出温退 をそれぞれ $1200^{\circ} \mathrm{C}$ および $1800^{\circ} \mathrm{C} ， 1300 \sim 1350^{\circ} \mathrm{C} お よ$ び $1800^{\circ} \mathrm{C}, 1400 \sim 1450^{\circ} \mathrm{C}$ およ゙ $1800^{\circ} \mathrm{C}$ として $\mathrm{H}_{2}$ の 抽出状沉を調べた. Table 4 はその結果を示す. 試料 の加熱温度 $1450^{\circ} \mathrm{C}$ 以下のとき，加熱の当初はやや速や かに $\mathrm{H}_{2}$ が抽出されるが，咕間の経過とともに $\mathrm{H}_{2}$ の抽 出速庭か減少し，終にはその温度における一定速度に達 する.もしとの最後の抽出速度か長䀦間にわたつて変ら

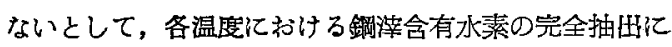
要する时間を計算するとつぎのとおりである。

温度 ${ }^{\circ} \mathrm{C} \quad 1200 \quad 1300 \sim 1350 \quad 1400 \sim 1450$

所要時間 (h) $52 \quad 22 \cdot 5 \quad 2 \cdot 2$

iii）酸性鋁䐠

仕上期の酸性鋼涻につき $1200 \sim 1250^{\circ} \mathrm{C}$ にわいて $\mathrm{H}_{\mathbf{2}}$ が完全に抽出されなくなるまで70 mn 抽出した後温度 を 1650〜 $1700^{\circ} \mathrm{C}$ に上昇させた。.その結果はつぎのでと くであつた.

Table 3. Extraction of $\mathrm{H}_{2}$ in basic oxidizing slag at successibly elevated temperatures by a vacuum furnace.

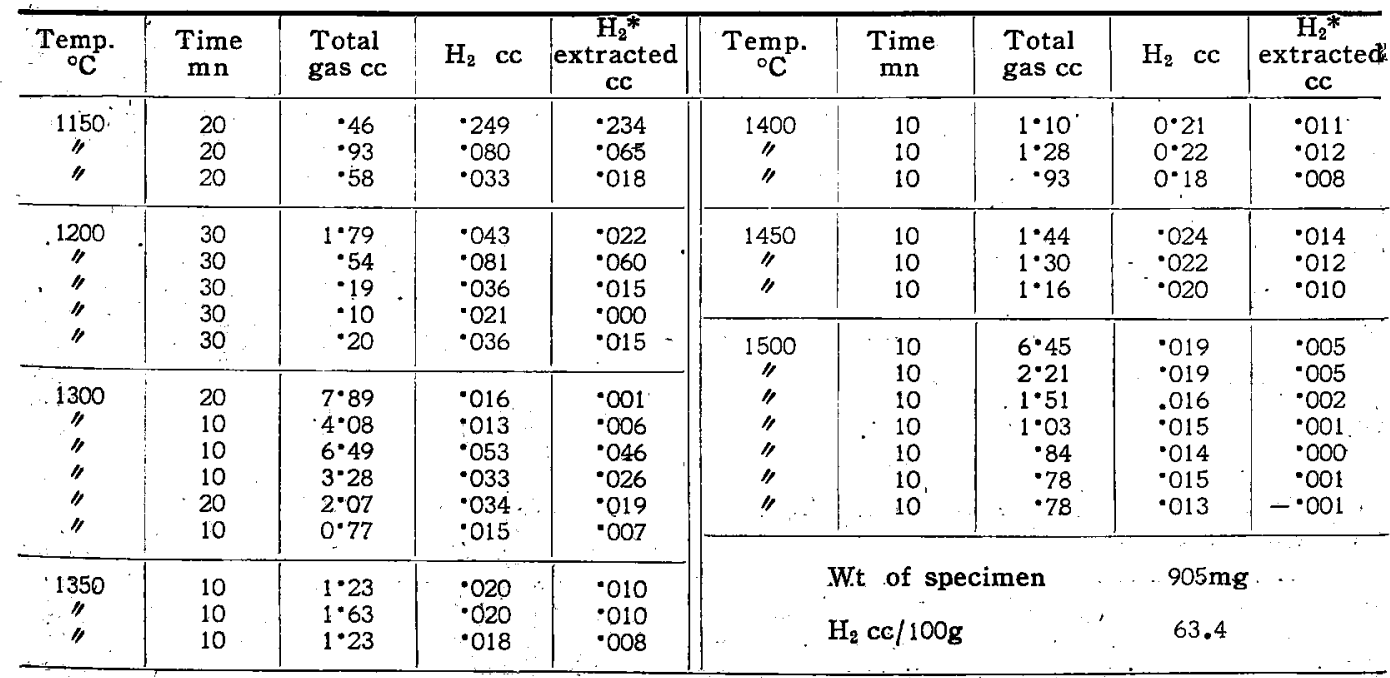

* Blank yalues subtracted 
Table 4.Extraction of $\mathrm{H}_{2}$ in basic reducing slag at various temperatures by a vacuum furnace.

\begin{tabular}{|c|c|c|c|}
\hline Extracting temp. ${ }^{\circ} \mathrm{C}$ & $\begin{array}{l}1200 \\
1800\end{array}$ & $\begin{array}{c}1300 / 1350 \\
1800\end{array}$ & $\begin{array}{c}1400 / 1450 \\
1800\end{array}$ \\
\hline $\begin{array}{l}\mathrm{H}_{2} \text { extracted at lower temp. } \\
\text { " } \quad \text { at higher temp. } \\
\text { Total amount in } \mathrm{cc} / 100 \mathrm{~g}\end{array}$ & $\begin{array}{l}39 \cdot 9(110) \\
154^{*} 2(60) \\
194^{*} 1\end{array}$ & $\begin{aligned} & 102 \cdot 5(110) \\
& 94 \cdot 5(60) \\
& 197 \cdot 0\end{aligned}$ & $\begin{array}{c}191 \cdot 0(100) \\
17 \cdot 0(25) \\
208 \cdot 0\end{array}$ \\
\hline
\end{tabular}

( ) means extracting tjme in $\mathrm{mn}$.

$1200 \sim 1250^{\circ} \mathrm{C} 70 \mathrm{mn}$ 抽耐䎲て $12 \cdot 9 \mathrm{cc} / 100 \mathrm{~g}$ $1650 \sim 1700^{\circ} \mathrm{C} 14 \mathrm{mn}$ 抽田にて $32 \cdot 9 \mathrm{cc} / 100 \mathrm{~g}$ 就 $45 \cdot 8 \mathrm{cc} / 100 \mathrm{~g}$

e) 若 察

以上の実験にて明らかな通り，鋼滓含有水素 $\left(\mathrm{H}_{2}\right.$ お よび $\mathrm{H}_{2} \mathrm{O}$ ) 注 $400^{\circ} \mathrm{C}$ 上上の真空加熱によつて発生する か，分析の笑用的速安にて抽田するためには $1400^{\circ} \mathrm{C}$ 以 止すなわち，ほぼ鎆涬の熔融点以上に真空加熱すること が必要である. Herasymenko および Dombrowskiの 行つた数 $\mathrm{mm}$ 大の粒状試料を $950^{\circ} \mathrm{C}$ にて具空加熱する 方洪で，銅滓含有水素艺完全に抽出することは望めない と思われる.小林氏のように微扮状鋼幥を $1200^{\circ} \mathrm{C} に て$ 長時開真空加熱すれれば，止素の完全抽代は不可能ではな い. けれども試料取扱中の吸湿を防ぐととが閶題となる 5 .

\section{III. 熱伝真度式水素計の精度向上について}

ここまで使用してきた水素計は，銅中の水素の迅速定

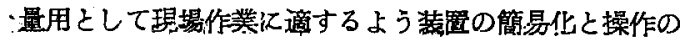
田速化を主眼没設計した。との装登でも抽出気体の $\mathrm{H}_{2}$ を精度よく分析できるが，研究室的な用途に $\mathrm{H}_{2}$ の微量 分析に適する装置を設計製作した。数度の試作改良を経 て到達した水素計は Fig. 3，Fig. 4 および Fig. 5 亿 示すとおりである. その要点は

i）熱层道度発信器を魔法瓶中の水水梄に入れ，槽内 に有孔隔壁を設けて発信器外壁に水片が直接接触するこ とを避け，現汼器により瞥内の水を流動せしめた，発信 器は薄肉銅管を使用した．しれにより指示筑答の迅速化 およひ安定化は極めて满足すべきものとなつた。一日を 通して 点の変動は $0.01 \mathrm{mV}$ 以内である.

ii）熱后導度の測定を一定の低王にて行うこととし

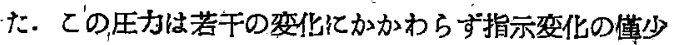
な 100 mimg とした.

iii）抽齿気体に微量含まるべき $\mathrm{CO}_{2}$ をアスカライト 飞よつて隆去し, 大型 McLeod 生方部 (約600cc) 亿 より総量を測り，ただちに水素計に気体を运入する構造

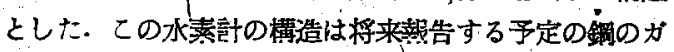

フ完全迅速分析装罡の母体となつており，その作動は䃌 めて精密である。

\section{IV. 試料より発する蒸着物による分析席害 について}

a）黒鈶坩堝による踢起石の連続分析

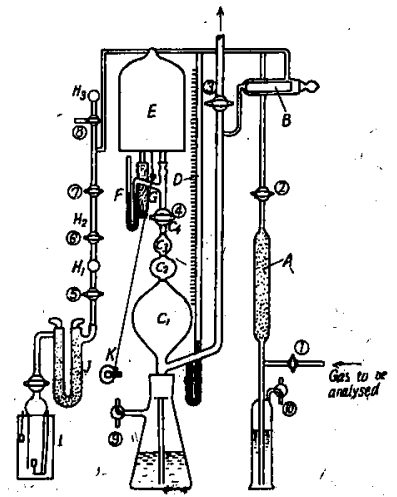

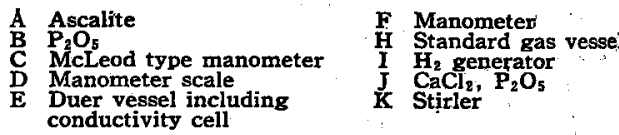

Fig. 3. Hydrogen meter by thermoconductivity method.

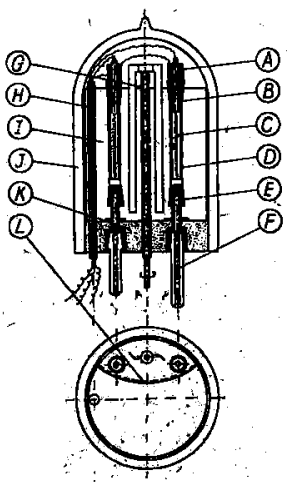

A Upper terminal

B Insulator

C Pt filament

D Cu tube

E.F Gas tube

G Stirler

H Conductor

I Ice water vessel

L. Cu network

Fig. 4. Thermoconductivity cell. 


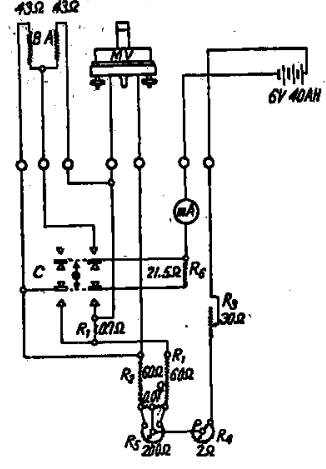

Fig. 5. Electric connectioñ of hydrogen meter.

黒捨咕堝を用いて数個の陽起石試料を逐次愹融抽出す ろと，分析值は一つの傾向をもつて变動する. その様子 は最初の試料の $\mathrm{H}_{2}$ 值がやや低く，2〜3 個目がやや高 く, 爾後漱減の倾向があろ.

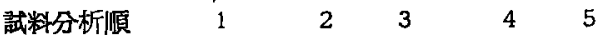

$\begin{array}{llllll}\mathrm{H}_{2} \% \text { (平场) } & 0.231 & 0.243 & 0.257 & 0.232 & 0.204\end{array}$ この傾向は試料投入前の镸㭙閒排気の影暨および試料よ

り生ずる蒸首物のゲッタ作用に基くものと考えられる。

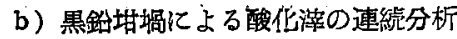

前節の陽起石におけると同槏の条件で塩基性雪気灯の

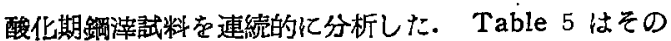
結果である．表中 A，B，Cの三系列は武料の砏片を逐 次黒釭坩堝に投入分析した結果を示し， $\mathrm{H}_{2}$ 定量值は第， 1 回目の試料加亮く，分析順序とともに低減する. 真空 怇の外壁を空冷の代りに水冷するとDのでとくこの傾向 が一層強く表われる.このことは器壁に主として附着す る蒸盖物のゲッタ作用を明白に示すすのである。 Eは試

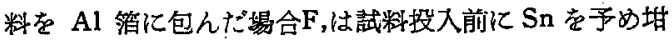

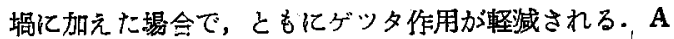
〜 Fの各系列はそれぞれ武料が相異するから系列間の分 析值は比較されないが，同一系列内において同一塊より 破䂶した武料の分析值が分析順序とともにこのように低 減するととは分析法として望ましくない，その対策とし て真空师の排気速宠を一層高めるととと，黒鈶畦城の代

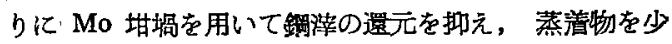
くする方法が若えられる。

\section{Mo 坩堝による真空熔虽}

Table 5. Hydrogen analysis of basic oxidizing slags by vacuum fusion in the graphite crucible.

\begin{tabular}{|c|c|c|c|c|c|c|c|c|c|c|}
\hline \multirow{2}{*}{$\begin{array}{c}\text { Exp. } \\
\text { No. }\end{array}$} & \multirow{2}{*}{$\begin{array}{c}\text { wt. of } \\
\text { speci- } \\
\text { men } \\
\text { mg. }\end{array}$} & \multicolumn{2}{|c|}{$\begin{array}{l}\text { Condition of } \\
\text { extraction }\end{array}$} & \multicolumn{2}{|c|}{$\begin{array}{c}\text { Gas extracted } \\
\text { cc }\end{array}$} & \multirow{2}{*}{$\begin{array}{c}\text { Blank } \\
\text { cc }\end{array}$} & \multirow{2}{*}{$\begin{array}{l}\mathrm{H}_{2} \\
\mathrm{cc}\end{array}$} & \multirow{2}{*}{$\begin{array}{c}\text { Temp. } \\
\text { factor } \\
\%\end{array}$} & \multirow{2}{*}{$\begin{array}{l}\mathrm{H}_{2} \\
\%\end{array}$} & \multirow{2}{*}{ Remarks } \\
\hline & & $\begin{array}{c}\text { Temp. } \\
{ }^{\circ} \mathrm{C}\end{array}$ & $\begin{array}{c}\text { Time } \\
\text { mn }\end{array}$ & Total & $\mathbf{H}_{2}$ & & & & & \\
\hline $\begin{array}{l}A-1 \\
A-2 \\
A-3\end{array}$ & $\begin{array}{r}118 \cdot 8 \\
88 \cdot 2 \\
103 \cdot 4\end{array}$ & $\begin{array}{c}1600 \\
" 1 \\
"\end{array}$ & $\begin{array}{l}25 \\
30 \\
35\end{array}$ & $\begin{array}{r}10^{\circ} 45_{8} \\
9 \cdot 76_{7} \\
9 \cdot 18_{5}\end{array}$ & $\begin{array}{l}0 \cdot 25_{7} \\
0 * 12_{9} \\
0 \cdot 15_{5}\end{array}$ & $\begin{array}{l}0.09_{1} \\
0 \cdot 10_{9} \\
0 \cdot 12_{1}\end{array}$ & $\begin{array}{l}0.16_{6} \\
0.02_{0} \\
0.02_{8}\end{array}$ & $\begin{array}{c}90 \cdot 1 \\
" 1 \\
" 1\end{array}$ & $\begin{array}{l}0^{\circ} 011_{2} \\
0^{\circ} 001_{8} \\
0^{\circ} 002_{2}\end{array}$ & $\begin{array}{l}\text { Vacuum vessel } \\
\text { ajr cooled }\end{array}$ \\
\hline $\begin{array}{l}\mathrm{B}-1 \\
\mathrm{~B}-2 \\
\mathrm{~B}-3 \\
\mathrm{~B}-4 \\
\mathrm{~B}-5\end{array}$ & $\begin{array}{l}43^{\circ} 6 \\
91 \cdot 7 \\
81 \cdot 2 \\
48^{*} 6 \\
53^{\circ} 9\end{array}$ & $\begin{array}{c}1600 \\
" 1 \\
" 1 \\
"\end{array}$ & $\begin{array}{l}30 \\
30 \\
30 \\
30 \\
30\end{array}$ & $\begin{array}{r}7 \cdot 22_{3} \\
10^{\circ} 98_{6} \\
10 \cdot 63_{9} \\
9 \cdot 48_{8} \\
10^{\circ} 55_{9}\end{array}$ & $\begin{array}{l}0.11_{6} \\
0.11_{5} \\
0.08_{0} \\
0.06_{8} \\
0.05_{8}\end{array}$ & $\begin{array}{l}0.03_{8} \\
0.03_{8} \\
0.03_{8} \\
0.03_{8} \\
0.03_{8}\end{array}$ & $\begin{array}{l}0.07_{8} \\
0.07_{B} \\
0.04_{2} \\
0.03_{0} \\
0.02_{0}\end{array}$ & $\begin{array}{c}92 \cdot 9 \\
" 1 \\
" 1 \\
" 1\end{array}$ & $\begin{array}{l}0^{\circ} 014_{8} \\
0^{\cdot} 006_{9} \\
0^{*} 004_{8} \\
0^{-} 005_{1} \\
0^{\cdot} 003_{1}\end{array}$ & Ditto \\
\hline $\begin{array}{l}\mathbf{C}-1 \\
\mathbf{C}-2 \\
\mathbf{C}-3 \\
\mathbf{C}-4\end{array}$ & $\begin{array}{r}49 * 3 \\
127 * 7 \\
45 * 1 \\
95 * 5\end{array}$ & $\begin{array}{c}1600 \\
" 1 \\
\text { " " }\end{array}$ & $\begin{array}{l}20 \\
20 \\
20 \\
20\end{array}$ & $\begin{array}{r}5 \cdot 23_{1} \\
16^{*} 22_{0} \\
4^{*} 71_{2} \\
8^{*} 34_{5}\end{array}$ & $\begin{array}{l}0.27_{8} \\
0 \cdot 19_{2} \\
0.12_{7} \\
0 \cdot 13_{6}\end{array}$ & $\begin{array}{l}0 * 10_{8} \\
0 * 10_{8} \\
0 * 10_{8} \\
0 * 10_{8}\end{array}$ & $\begin{array}{l}0.17_{0} \\
0.084 \\
0.01_{9} \\
0.028\end{array}$ & $\begin{array}{c}90 * 1 \\
" 1 \\
" 1\end{array}$ & $\begin{array}{l}0^{-} 027_{7} \\
0.005_{8} \\
0^{-} 003_{4} \\
0^{-} 002_{4}\end{array}$ & $\begin{array}{c}\text { Ditto } \\
.\end{array}$ \\
\hline $\begin{array}{l}\mathrm{D}-1 \\
\mathrm{D}-2 \\
\mathrm{D}-3 \\
\mathrm{D}-4 \\
\mathrm{D}-5\end{array}$ & $\begin{array}{r}71 \cdot 3 \\
171 \cdot 8 \\
73 \cdot 2 \\
57 \cdot 2 \\
64 * 3\end{array}$ & $\begin{array}{l}1600 \\
" 1 \\
" 1 \\
" 1\end{array}$ & $\begin{array}{l}30 \\
30 \\
30 \\
30 \\
30\end{array}$ & $\begin{array}{r}7 \cdot 61_{9} \\
14 \cdot 30_{5} \\
10^{*} 61_{4} \\
8 \cdot 13_{2} \\
12 \cdot 34_{0}\end{array}$ & $\begin{array}{l}0.07_{1} \\
0.022_{0} \\
0.00_{6} \\
0.01_{6} \\
0.01_{1}\end{array}$ & $\begin{array}{l}0.00_{3} \\
0.00_{3} \\
0.00_{8} \\
0.00_{3} \\
0.00_{3}\end{array}$ & $\begin{array}{l}0.06 \mathrm{~s} \\
0.01_{7} \\
0.00_{8} \\
0.01_{8} \\
0.000_{8}\end{array}$ & $\begin{array}{c}90 * 4 \\
" 1 \\
" 1 \\
" 1\end{array}$ & 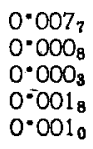 & $\begin{array}{l}\text { Vacuum vessel } \\
\text { water cooled }\end{array}$ \\
\hline $\begin{array}{l}\mathbf{E}-1 \\
\mathbf{E}-2 \\
\mathbf{E}-4 \\
\mathbf{E}-\mathbf{5}\end{array}$ & $\begin{array}{r}55^{*} 4 \\
61 \cdot 9 \\
111 \cdot 3 \\
111.7\end{array}$ & $\begin{array}{c}1600 \\
" 1 \\
" y \\
" 1\end{array}$ & $\begin{array}{l}25 \\
35 \\
32 \\
30\end{array}$ & $\begin{array}{l}9 \cdot 19_{3} \\
4 \cdot 42_{0} \\
6 \cdot 44_{6} \\
6 \cdot 40_{5}\end{array}$ & $\begin{array}{l}0.07_{1} \\
0.08_{6} \\
0.10_{6} \\
0.09_{9}\end{array}$ & $\begin{array}{l}0^{-} 03_{2} \\
0^{-} 04_{5} \\
0^{-0} 04_{1} \\
0^{-} 03_{8}\end{array}$ & $\begin{array}{l}0.03_{9} \\
0.04_{1} \\
0.06_{5} \\
0.06_{1}\end{array}$ & $\begin{array}{c}91 \cdot 0 \\
" 1 " \\
" 1\end{array}$ & $\begin{array}{l}0.005_{7} \\
0.005_{4} \\
0.004_{7} \\
0.004_{4}\end{array}$ & $\begin{array}{l}\text { Vacuum vessel } \\
\text { air cooled } \\
\text { specimen was } \\
\text { covered with Al } \\
\text { foil }\end{array}$ \\
\hline $\begin{array}{l}F-1 \\
F-2 \\
F-3 \\
F-4\end{array}$ & $\begin{array}{l}52 * 1 \\
21 \cdot 4 \\
58 \cdot 7 \\
50 \cdot 5\end{array}$ & $\begin{array}{c}1400 \\
" 1 \\
" 2\end{array}$ & $\begin{array}{l}22 \\
20 \\
20 \\
20\end{array}$ & $\begin{array}{l}6 \cdot 61_{5} \\
3 \cdot 68_{2} \\
7 \cdot 30_{4}^{i} \\
6 \cdot 37_{3}\end{array}$ & $\begin{array}{l}0.11_{1}^{1} \\
0.06_{2} \\
0.06_{8} \\
0.05_{5}\end{array}$ & $\begin{array}{l}0.022_{\theta} \\
0.02 \beta \\
0.02 \beta \\
0.02 \beta\end{array}$ & $\begin{array}{l}0.08_{2} \\
0.04_{0} \\
0.04_{2} \\
0.028\end{array}$ & $\begin{array}{c}89,8 \\
4\end{array}$ & $\begin{array}{l}0.012_{6} \\
0.006_{9} \\
0.005_{7} \\
0.004_{6}\end{array}$ & $\begin{array}{l}\text { Sn added in the } \\
\text { crucible }\end{array}$ \\
\hline
\end{tabular}




\section{a ) 装 梁}

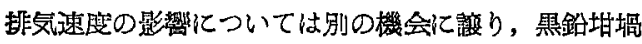
の代りに Mo 咕城を用いるとやや满足すべき結果か得

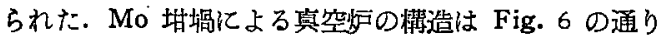
である. 炬体，発熱部，保温部怯往来の炭素螺续师と同 一である．黒鈆制の咕城容器の代りに Mo 製の容器を設

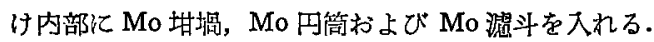

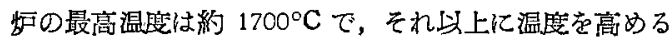

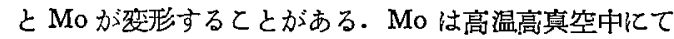
$\mathrm{H}_{2} \mathrm{O}$ と反応して $\mathrm{Mo}+3 \mathrm{H}_{2} \mathrm{O}=\mathrm{MoO}_{3}+3 \mathrm{H}_{2}$ により $\mathrm{H}_{2} \mathrm{O}$

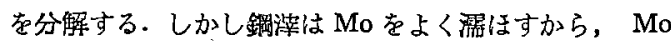

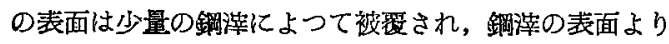
発する $\mathrm{H}_{2} \mathrm{O}$ は $\mathrm{Mo}$ と反応せずに抽屽されるととがあ ろ.乙の装置て陽起石武料 10 個を分析した平均值は

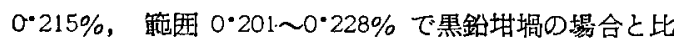
酸して約 $10 \%$ 低值を与元る.

抽球気体中の $\mathrm{H}_{2} \mathrm{O}$ 孛 $\mathrm{H}_{2}$ 亿变化させるには，Herasymenko および Dombrowski 耐氏做つて Mn よる $\mathrm{H}_{2} \mathrm{O}$ の分解反応を利用するのか簢便である，内径

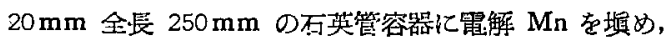
外部より炝で加熱する．Fig.7は装置の接続図である.

b) Mn の温屡の選定

青山，岡両氏9引とよると $\mathrm{Mn}+\mathrm{H}_{2} \mathrm{O}=\mathrm{MnO}+\mathrm{H}_{2}$ の平

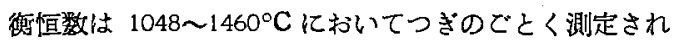
ている.

$$
\log \mathrm{Kp}=8504 / \mathrm{T}-2 \cdot 035
$$

各温鹿の $\mathrm{Mn}$ 亿平衡する $\mathrm{P}_{\mathrm{H}_{2}} \mathrm{O}$ は $\mathrm{P}_{2}+\mathrm{PH}_{2} \mathrm{O}=1$ atm おいて

$$
\begin{aligned}
& \text { 温度 }{ }^{\circ} \mathrm{C} 1460 \quad 1341 \quad 1271 \\
& \mathrm{PH}_{20} \quad 2.55 \times 10^{-4} \quad 5.87 \times 10^{-5} \quad 1.80 \times 10^{-5} \\
& 1161 \quad 1048 \\
& 4 \cdot 85 \times 10^{-6} \quad 8 \cdot 61 \times 10^{-7}
\end{aligned}
$$

と報告され，1048 ${ }^{\circ} \mathrm{C}$ より低温域ではとの反応は一層右 欢に進行し，Mn による $\mathrm{H}_{2} \mathrm{O}$ の分解梳はほ完全と見做 される，乙れを分析装置に用いるには，反应速度が問題 である.よつて Mn の温度を $500^{\circ}, 600^{\circ}, 700^{\circ}$ およ び $800^{\circ} \mathrm{C}$ 亿保ち，既知容の室温飽和水蒸気学通過せし めて生成する $\mathrm{H}_{2}$ を捕集し， $\mathrm{H}_{2} \mathrm{O}$ の分解率を求めた。 その結果は水蒸気の科量が誤差を生ずる恐㣗はあるが， Table 6 のように 500 $800^{\circ} \mathrm{C}$ 亿保つた Mn 圓を 1 回 通過させれば $\mathrm{H}_{2} \mathrm{O}$ の分解はほぼ定量的であると認めら れる.

つぎ Mn の温度を $500^{\circ}, 600^{\circ}, 700^{\circ} \mathrm{C}$ おび 800 ${ }^{\circ} \mathrm{C}$ 亿保方既知量の $\mathrm{H}_{2}$ を通過せしめてその吸収作用を

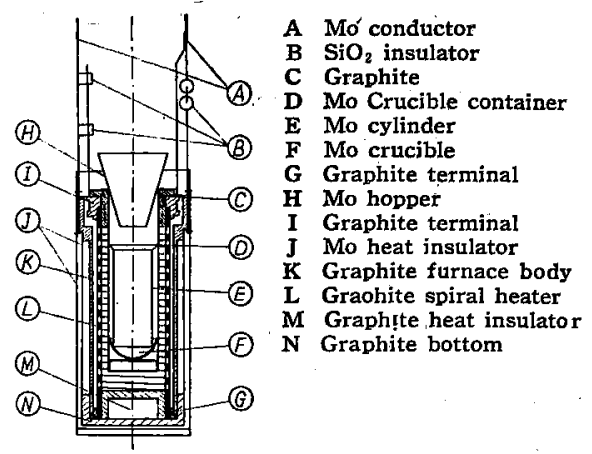

Fig. 6. Vacuum furnace

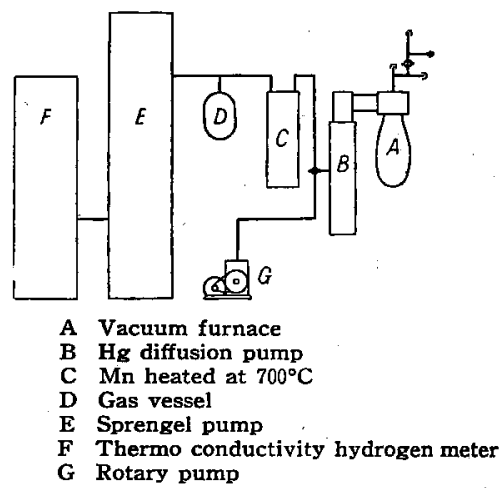

Fig. 7. Vacuum fusion apparatus for analysing hydrogen in steelmaking slags.

Table 6. $\quad \mathrm{H}_{2} \mathrm{O}+\mathrm{Mn}=\mathrm{H}_{2}+\mathrm{Mn}$ Oे reation.

\begin{tabular}{c|c|c|}
\hline \multirow{2}{*}{ Temp. of Mn $_{{ }^{\circ} \mathrm{C}}$} & \multicolumn{2}{|c|}{ Decomposed $\mathrm{H}_{2} \mathrm{O} \%$} \\
\cline { 2 - 3 } & Range & Mean \\
\hline 500 & $95 \cdot 6 \sim 104^{\circ} \mathrm{O}$ & $100^{\circ} 5^{\circ}$ \\
600 & $98^{\circ} 1 \sim 104^{\circ} 0$ & $100 \cdot 6$ \\
700 & $99.3 \sim 101^{\circ} 8$ & $100^{\circ} 5$ \\
800 & $100 \cdot 6 \sim 101^{\circ} 6$ & $100^{\circ} 9$ \\
\hline
\end{tabular}

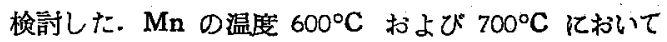
$\mathrm{H}_{2}$ の旪収作用仙証められない. $800^{\circ} \mathrm{C}$ 亿わいては平均 $1.8 \%$ (3 回) 簡囲 $1.3 \sim 2.3 \% \mathrm{H}_{2}$ 方吸扠される. とれ は Mn の蒸着认よるゲッタ作用である. また Mn の㴜 庭を $500^{\circ} \mathrm{C}$ まで下げると吸収作用が認められた。てれ は温度降下による吸着能の表われであうう。とれを要す る Mn は $600^{\circ} \sim 700^{\circ} \mathrm{C}$ の一定温度に保持することか⿱ 必要である.そうすれば $\mathrm{H}_{2} \mathrm{O}$ を定量的保 $\mathrm{H}_{2}$ 亿慗換す るととが可能である.

c）Mo 坩晭による陽起石の連続分析 
Table 7. Hydrogen analysis of actinolite by vacuum fusion in Mo crucible.

\begin{tabular}{|c|c|c|c|c|c|c|c|c|c|}
\hline \multirow{2}{*}{$\begin{array}{l}\text { Exp. } \\
\text { No. }\end{array}$} & \multirow{2}{*}{$\begin{array}{l}\text { Wt. of } \\
\text { speci- } \\
\text { men } \\
\text { mg }\end{array}$} & \multicolumn{2}{|c|}{$\begin{array}{l}\text { Condition of } \\
\text { extraction }\end{array}$} & \multicolumn{2}{|c|}{$\begin{array}{c}\text { Gas exctracted } \\
\text { cc }\end{array}$} & \multirow{2}{*}{$\begin{array}{c}\text { Blank } \\
\text { cc }\end{array}$} & \multirow{2}{*}{$\begin{array}{l}\mathrm{H}_{2} \\
\mathrm{cc}\end{array}$} & \multirow{2}{*}{$\begin{array}{c}\text { Temp. } \\
\text { factor } \\
\%\end{array}$} & \multirow{2}{*}{$\mathrm{H}_{2} \%$} \\
\hline & & $\begin{array}{l}\text { Temp. } \\
{ }^{\circ} \mathrm{C}\end{array}$ & $\begin{array}{c}\text { Time } \\
\text { mn }\end{array}$ & Total & $\mathrm{H}_{2}$ & & & & \\
\hline $\begin{array}{l}A-1 \\
A-2 \\
A-3 \\
A-4 \\
A-5\end{array}$ & $\begin{array}{l}28^{\cdot} 5 \\
27^{*} 7 \\
25^{\circ} \cdot 2 \\
23^{\circ} 4 \\
32^{\cdot} 6\end{array}$ & $\begin{array}{c}1600 \\
" 1 \\
" 1 \\
" 1\end{array}$ & $\begin{array}{r}30 \\
30 \\
30 \\
-30 \\
30\end{array}$ & $\begin{array}{l}1 \cdot 28_{8} \\
1 \cdot 25_{9} \\
1 \cdot 04_{8} \\
1 \cdot 05_{4} \\
1 \cdot 53_{9}\end{array}$ & $\begin{array}{l}0.99_{8} \\
0.92_{4} \\
0 \cdot 85_{5} \\
0 \cdot 79_{4} \\
1 \cdot 15_{1}\end{array}$ & $\begin{array}{l}0.08_{8} \\
0.08_{8} \\
0.08_{8} \\
0.08_{8} \\
0.08_{8}\end{array}$ & $\begin{array}{l}0 \cdot 90_{4} \\
0 \cdot 83_{5} \\
0 \cdot 76_{8} \\
0 \cdot 70_{5} \\
1.06_{2}\end{array}$ & $\begin{array}{c}89 \cdot 5 \\
\text { "1 } \\
\text { "1 } \\
\text { " }\end{array}$ & $\begin{array}{l}0 \cdot 25_{3} \\
0 \cdot 24_{1} \\
0 \cdot 24_{3} \\
0 \cdot 24_{1} \\
0 \cdot 26_{0}\end{array}$ \\
\hline $\begin{array}{l}\mathrm{B}-1 \\
\mathrm{~B}-2 \\
\mathrm{~B}-3 \\
\mathrm{~B}-4 \\
\mathrm{~B}-5 \\
\mathrm{~B}-6 \\
\mathrm{~B}-7 \\
\mathrm{~B}-8 \\
\mathrm{~B}-9\end{array}$ & $\begin{array}{l}26 \cdot 8 \\
27 \cdot 6 \\
33 \cdot 2 \\
29 \cdot 1 \\
27 \cdot 6 \\
30 \cdot 7 \\
31 \cdot 6 \\
36 \cdot 5 \\
36^{*} \cdot 4\end{array}$ & $\begin{array}{l}1600 \\
" 1 \\
" 1 \\
" 1 \\
" 1 \\
" 1 \\
" 1 \\
" 1\end{array}$ & $\begin{array}{l}30 \\
30 \\
30 \\
30 \\
30 \\
30 \\
30 \\
30 \\
30\end{array}$ & $\begin{array}{l}1 \cdot 40_{9} \\
1 \cdot 39_{1} \\
1 \cdot 46_{9} \\
1 \cdot 33_{9} \\
0 \cdot 95_{6} \\
1 \cdot 039 \\
1 \cdot 21_{1} \\
1 \cdot 30_{1} \\
1 \cdot 23_{3}\end{array}$ & $\begin{array}{l}1 \cdot 08_{0} \\
1 \cdot 02_{0} \\
1 \cdot 17_{2} \\
1 \cdot 03_{8} \\
0 \cdot 89_{2} \\
0 \cdot 93_{7} \\
0 \cdot 94_{4} \\
1 \cdot 12_{8} \\
1 \cdot 15_{8}\end{array}$ & $\begin{array}{l}0.22_{1} \\
0 \cdot 22_{1} \\
0.22_{1} \\
0 \cdot 22_{1} \\
0.04_{5} \\
0.04_{5} \\
0.04_{5} \\
0 \cdot 04_{5} \\
0.044_{5}\end{array}$ & $\begin{array}{l}0.85_{\theta} \\
0.799_{\theta} \\
0.955_{1} \\
0.81_{2} \\
0.84_{7} \\
0.89_{2} \\
0.89_{\theta} \\
1.071_{8} \\
1.11_{8}\end{array}$ & $\begin{array}{c}90^{\circ} 4 \\
\text { "1 } \\
\text { "1" } \\
911^{\circ} 0 \\
\text { " } \\
\text { "" } \\
\text { " }\end{array}$ & $\begin{array}{l}0.25_{8} \\
0 \cdot 23_{4} \\
0 \cdot 23_{1} \\
0 \cdot 22_{5} \\
0 \cdot 24_{8} \\
0 \cdot 24_{8} \\
0 \cdot 23_{1} \\
0 \cdot 24_{0} \\
0 \cdot 24_{8}\end{array}$ \\
\hline
\end{tabular}

Table 7 は Mo 唗城けよる陽起石の分析皘果である。 分析值の变動が少く，抽计気体中の $\mathrm{H}_{2}$ 濃度が高い. 陽 迅石の水素分析值は 14 回平均 $0.242 \%$ であり，黒鉆 地城による 48回平均 $0.243 \%$ および Table 1 の理論 值 $0.246 \%$ と分析誤差内で一致する.

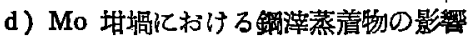

黒鈴塔堝を用いた場合に生じた鋼涬蒸着物のゲツタ作 用が Mo 畦堝の使用によつて軽減されるか石かをたし かめるためつぎの実験を行なつた.

满堝中に投入された武料は愹融して含有水素を放田す ろが，一方 Mo と反店して㒖小ながら還元され，構成 成分の金属蒸気を発生し，また炭化物およひ酸化物の蒸 気を生ずる. 試淤投人後の時間経過とともに真空妒の器 壁はこれら蒸盖物により次第に黒色を呈する. 黒鈶畦堝 の場合と同様に試粼投入後の畤間経過とともに蒸着物の
量を増しその $\mathrm{H}_{2}$ 西盖作用も大きくなると予測される.

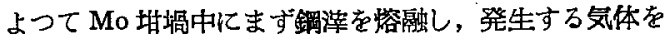
$30 \mathrm{mn}$ 抽出し, ついて陽起石試料を逐次投入分析して, その水素分析值に障害を与えるか否かを検討した。

Table 8 亿よると, 酸化涻，還元涬の何れの埸合も 第2 番目の陽起石武料までは分析障害が譛められない. 酸化涻の場合は第 3 番目の陽起石すなわち鋼㵏投入後 $105 \mathrm{mn}$ に投入した 陽起石試料以後は明らかに水素㑤が

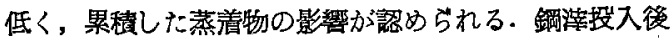
およそ $100 \mathrm{mn}$ は蒸着物の影響は無視される. 1 試翻の

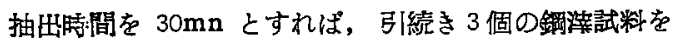
同一の Mo 坩堝にて分折するてとが可能である.

\section{VI. 鋼涬試料の採取，取扱と分析值の再現性}

\section{a) 鋼湝試料の採取と取扱}

Table 8. Effect of getter action of vaporized slag on hydrogen analysis of actinolite specimens.

\begin{tabular}{|c|c|c|c|c|c|c|c|c|c|c|c|}
\hline \multirow{2}{*}{$\begin{array}{l}\text { Exp. } \\
\text { No. }\end{array}$} & \multirow[b]{2}{*}{ Specimen } & \multirow{2}{*}{$\begin{array}{l}\text { Wt. } \\
\text { mg }\end{array}$} & \multirow{2}{*}{ Time } & \multicolumn{2}{|c|}{ Extraction } & \multicolumn{2}{|c|}{$\begin{array}{c}\text { Gas extracted } \\
\text { cc }\end{array}$} & \multirow{2}{*}{$\begin{array}{c}\text { Blank } \\
\text { cc }\end{array}$} & \multirow{2}{*}{$\begin{array}{l}\mathrm{H}_{2} \\
\mathrm{cc}\end{array}$} & \multirow{2}{*}{$\begin{array}{c}\text { Temp. } \\
\text { correc- } \\
\text { tion } \\
\%\end{array}$} & \multirow{2}{*}{$\mathrm{H}_{2} \%$} \\
\hline & & & & $\begin{array}{c}\text { Temp. } \\
{ }^{\circ} \mathrm{C}\end{array}$ & $\begin{array}{l}\text { Time } \\
\text { mn }\end{array}$ & Total & $\mathrm{H}_{2}$ & & & & \\
\hline$A-1$ & \multirow{3}{*}{$\begin{array}{c}\text { Actinolite } \\
\text { Oxidizing } \\
\text { slag } \\
\text { Actinolite } \\
\text { " } \\
" 1\end{array}$} & $10 \cdot 57$ & $10^{10}$ & 1550 & 20 & $\cdot 45_{6}$ & $\cdot 369$ & $\cdot 06_{0}$ & $\cdot 3 \mathrm{O}_{9}$ & $92 \cdot 9$ & $\cdot 24_{2}$ \\
\hline$A-2$ & & $498 \cdot 68$ & $10^{80}$ & " & 30 & $\cdot 49_{7}$ & $\cdot 37_{6}$ & $\cdot 09_{1}$ & $\cdot 28_{5}$ & " & $.004_{7}$ \\
\hline $\begin{array}{l}A-3 \\
A-4 \\
A-5 \\
A-6\end{array}$ & & $\begin{array}{r}13 \cdot 66 \\
6 \cdot 22 \\
18^{*} 27 \\
16^{*} 84\end{array}$ & $\begin{array}{l}11^{04} \\
11^{87} \\
12^{18} \\
13^{20}\end{array}$ & " & $\begin{array}{l}30 \\
30 \\
30 \\
35\end{array}$ & $\begin{array}{l}\cdot 60_{5} \\
\cdot 32_{3} \\
\cdot 66_{8} \\
\cdot 66_{5}\end{array}$ & $\begin{array}{r}.51_{6} \\
\cdot 28_{0} \\
\cdot 57_{8} \\
\cdot 57_{5}\end{array}$ & $\begin{array}{l}\cdot 09_{1} \\
\cdot 09_{1} \\
\cdot 09_{1} \\
\cdot 10_{5}\end{array}$ & $\begin{array}{r}\cdot 42_{5} \\
\cdot 18_{9} \\
\cdot 49_{6} \\
\cdot 47_{0}\end{array}$ & $\begin{array}{l}\text { ", } \\
\text { "1 } \\
\text { ", }\end{array}$ & $\begin{array}{l}\cdot 25_{8} \\
\cdot 25_{4} \\
\cdot 22_{5} \\
\cdot 23_{1}\end{array}$ \\
\hline$B-1$ & \multirow{3}{*}{$\begin{array}{c}\text { Actinolite } \\
\text { Reducing } \\
\text { slag } \\
\text { Actingolite } \\
\text { " }\end{array}$} & $10^{\circ} 03$ & $14^{15}$ & 1550 & 20 & $\cdot 46_{0}$ & $\cdot 37_{8}$ & $\cdot 070$ & $\cdot 3 \mathrm{O}_{3}$ & $93 \cdot 5$ & $\cdot 254$ \\
\hline$B-2$ & & $397 * 42$ & $14^{40}$ & '" & 30 & $\cdot 21_{5}$ & $\cdot 15_{9}$ & $\cdot 12_{5} *$ & $\cdot 03_{4}$ & " & $\cdot 00 \mathrm{O}_{7}$ \\
\hline $\begin{array}{l}B-3 \\
B-4\end{array}$ & & $\begin{array}{l}7 \cdot 76 \\
5 \cdot 31\end{array}$ & $\begin{array}{l}15^{10} \\
15^{45}\end{array}$ & "1" & $\begin{array}{l}25 \\
20\end{array}$ & $\begin{array}{l}\cdot 38_{1} \\
\cdot 28_{8}\end{array}$ & $\begin{array}{l}\cdot 31_{g} \\
\cdot 23_{1}\end{array}$ & $\begin{array}{l}\cdot 08_{0} \\
\cdot 07_{0}\end{array}$ & $\begin{array}{l}\cdot 23_{8} \\
\cdot 14_{1}\end{array}$ & "1" & $\begin{array}{l}\cdot 25_{8} \\
\cdot 25_{8}\end{array}$ \\
\hline
\end{tabular}

* Including blank value of $\mathrm{Sn}$ container. 
鋼㴖は吸湿しやすいから武料の採取，保存および分析 操作の間の吸湿をできるだけ防ぐ必要がある，炻内より スプーンにて探取した酸化㵏は, 手早く破砕し $15 \mathrm{~mm} \varnothing$ $\times 50 \mathrm{~mm}$ の硝子製科量瓶に入れ，栓をして $\mathrm{P}_{2} \mathrm{O}_{5}$ を入 れた乾燥瓶に蓄える. 還元洣は粉鹿化しやすいから， Sn 䇴製の $5 \mathrm{~mm} \phi \times 25 \mathrm{~mm}$ の底を封じた容器を上記科 量瓶に入れて置き，破砕したまだ粉塵化しない熱い塊状 の試料を手早く Sn 䈃容器に入れ, 上部を封じ, 科量瓶 に栓をして $\mathrm{P}_{2} \mathrm{O}_{5}$ 乾燥瓶に蓄える. 武料を科量瓶汃ら大 気中取出すのは, 試料を真空炉の武料装入器に入れる 直前の数 sec 亿すぎない. Fig. 8 は科量瓶，乾燥瓶を 示す.

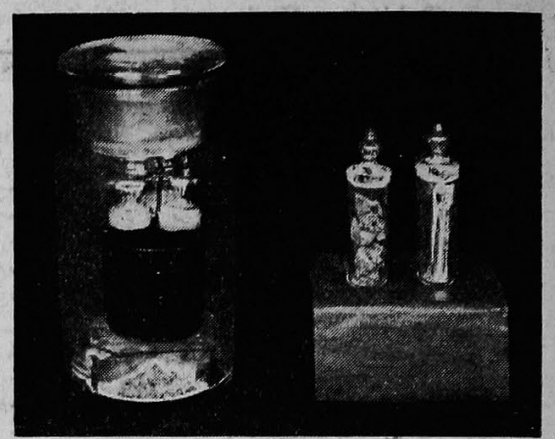

Fig. 8. Slag specimen, weighing bottle and $\mathrm{P}_{2} \mathrm{O}_{5}$ desiccator.

Table 9. Reproducibility of analysis.

\begin{tabular}{|c|c|c|c|c|c|c|c|c|c|c|c|c|}
\hline \multirow{2}{*}{ 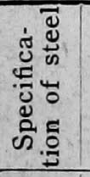 } & \multirow{2}{*}{ 点。 } & \multirow{2}{*}{$\begin{array}{l}\text { Speci- } \\
\text { men } \\
\text { wt } \\
\text { mg }\end{array}$} & \multicolumn{2}{|c|}{ Extraction } & \multicolumn{2}{|c|}{$\begin{array}{c}\text { Gas extracted } \\
\text { cc }\end{array}$} & \multicolumn{2}{|c|}{ Blank cc } & \multirow{2}{*}{$\begin{array}{l}\text { Temp. } \\
\text { correc- } \\
\text { tion } \\
\%\end{array}$} & \multirow{2}{*}{$\begin{array}{c}\mathrm{H}_{2} \\
\mathrm{cc} / 100 \mathrm{~g}\end{array}$} & \multicolumn{2}{|c|}{ Deviation } \\
\hline & & & $\begin{array}{l}\text { Temp } \\
{ }^{\circ} \mathrm{C}\end{array}$ & $\underset{\mathrm{mn}}{\text { Time }}$ & Total & $\mathrm{H}_{2}$ & Sn & Furnace & & & $\mathrm{cc} / 100 \mathrm{~g}$ & $\begin{array}{c}\text { with } \\
\text { mean } \\
\%\end{array}$ \\
\hline \multirow{2}{*}{$\underset{90}{\mathrm{SCr}}$} & $\mathrm{R}$ & $\begin{array}{l}560 \cdot 39 \\
633 \cdot 90\end{array}$ & $\begin{array}{c}1600 \\
" 1\end{array}$ & $\begin{array}{l}30 \\
" 1\end{array}$ & $\begin{array}{l}\cdot 30_{2} \\
\cdot 28_{4}\end{array}$ & $\begin{array}{l}\cdot 24_{0} \\
\cdot 22_{6}\end{array}$ & $\begin{array}{l}\cdot 02_{2} \\
\cdot 02_{2}\end{array}$ & $\cdot 06_{3}$ & $\begin{array}{l}92 \cdot 5 \\
92 \cdot 5\end{array}$ & $\begin{array}{l}25^{\circ} \cdot 8 \\
24^{\circ}\end{array}$ & $1 \cdot 1$ & \\
\hline & $\mathrm{R}$ & $\begin{array}{l}400 \cdot 63 \\
773 \cdot 62\end{array}$ & $\begin{array}{l}1600 \\
" 1\end{array}$ & $\begin{array}{l}40 \\
" 1\end{array}$ & $\begin{array}{l}\cdot 43_{8} \\
\cdot 44_{9}\end{array}$ & $\begin{array}{l}\cdot 32_{4} \\
\cdot 39_{0}\end{array}$ & $\begin{array}{l}\cdot 02_{2} \\
\cdot 02_{2}\end{array}$ & $\begin{array}{l}\cdot 17_{3} \\
\cdot 10_{6}\end{array}$ & $\begin{array}{l}93 \cdot 5 \\
93 \cdot 5\end{array}$ & $\begin{array}{l}30^{\circ}{ }_{2} \\
31^{\circ}\end{array}$ & $1 \cdot 5$ & $4 \cdot 9$ \\
\hline \multirow{2}{*}{$\underset{6}{\text { SUP }}$} & $\mathrm{R}$ & $\begin{array}{l}512 \cdot 09 \\
44 ! \cdot 95 \\
\end{array}$ & $\begin{array}{c}1600 \\
" 1\end{array}$ & $\begin{array}{l}30 \\
" 1\end{array}$ & $\begin{array}{l}\cdot 30_{4} \\
\cdot 227\end{array}$ & $\begin{array}{l}\cdot 23_{3} \\
\cdot 17_{4}\end{array}$ & $\begin{array}{l}\cdot 02_{2} \\
\cdot 02_{2}\end{array}$ & $\begin{array}{l}\cdot 029 \\
\cdot 029\end{array}$ & $\begin{array}{l}92 \cdot 5 \\
92 \cdot 5\end{array}$ & $\begin{array}{l}32^{\circ} \cdot 8 \\
25^{\circ} \\
8\end{array}$ & $7 \cdot 0$ & $24^{\circ} 0$ \\
\hline & $\mathrm{T}$ & $\begin{array}{l}708 \cdot 02 \\
738 \cdot 31 \\
601 \cdot 95\end{array}$ & $\begin{array}{c}1600 \\
" 1 \\
" 1\end{array}$ & $\begin{array}{l}30 \\
" 1 " \\
" 1\end{array}$ & $\begin{array}{l}\cdot 25_{4} \\
\cdot 25_{5} \\
\cdot 25_{0}\end{array}$ & $\begin{array}{l}\cdot 19_{5} \\
\cdot 18_{9} \\
\cdot 20_{6}\end{array}$ & $\begin{array}{l}\cdot 02_{2} \\
\cdot 02_{2} \\
\cdot 02_{2}\end{array}$ & $\begin{array}{l}\cdot 07_{0} \\
\cdot 07_{0} \\
\cdot 07_{8}\end{array}$ & $\begin{array}{l}94 \cdot 1 \\
94 \cdot 1 \\
93 \cdot 7\end{array}$ & $\begin{array}{l}13^{\circ} 7 \\
12^{\circ} 3^{3} \\
16^{\circ}\end{array}$ & $4^{\bullet}{ }_{2}$ & $24^{\circ} 0$ \\
\hline $\begin{array}{l}4 \\
0 \\
\infty \\
\text { ñ } \\
n\end{array}$ & $\mathrm{~T}$ & $\begin{array}{r}805 \cdot 51 \\
656 \cdot 54 \\
1007 \cdot 77\end{array}$ & $\begin{array}{l}1600 \\
" 1 " \\
" 1\end{array}$ & $\begin{array}{l}20 \\
1 " \\
" 1\end{array}$ & $\begin{array}{l}\cdot 23_{6} \\
\cdot 25_{5} \\
\cdot 37_{9}\end{array}$ & $\begin{array}{l}\cdot 18_{7} \\
\cdot 218 \\
\cdot 290\end{array}$ & $\begin{array}{l}\cdot 02_{2} \\
\cdot 02_{2} \\
\cdot 02_{2}\end{array}$ & $\begin{array}{l}\cdot 03_{0} \\
\cdot 08_{1} \\
\cdot 08_{1}\end{array}$ & $\begin{array}{l}94 \cdot 5 \\
94 \cdot 1 \\
94 \cdot 1\end{array}$ & $\begin{array}{l}15^{\circ} 8^{\circ} \\
16^{\circ} \\
17^{\circ}\end{array}$ & $1{ }^{\circ}$ & $10^{\circ}$ \\
\hline \multirow{2}{*}{$\sum_{\substack{\infty \\
0}}^{\infty}$} & 0 & $\begin{array}{l}207 \cdot 83 \\
234 \cdot 02\end{array}$ & $\begin{array}{c}1500 \\
" 1\end{array}$ & $\begin{array}{l}25 \\
\prime \prime\end{array}$ & $\begin{array}{l}\cdot 44_{7} \\
\cdot 50_{4}\end{array}$ & $\begin{array}{l}\cdot 33_{4} \\
\cdot 43_{2}\end{array}$ & - & $\begin{array}{l}\cdot 02_{2} \\
\cdot 02_{2}\end{array}$ & $\begin{array}{l}94 \cdot 8 \\
94 \cdot 8\end{array}$ & $\begin{array}{l}142^{\circ} \\
166^{\circ}\end{array}$ & $16^{\circ}$ & $10^{\circ}$ \\
\hline & $\mathrm{R}$ & $\begin{array}{l}645 \cdot 55 \\
518 \cdot 57\end{array}$ & $\begin{array}{c}1600 \\
11\end{array}$ & $\begin{array}{l}30 \\
" 1\end{array}$ & $\begin{array}{l}\cdot 36_{6} \\
\cdot 30_{6}\end{array}$ & $\begin{array}{l}\cdot 28_{2} \\
\cdot 21_{5}\end{array}$ & $\begin{array}{l}\cdot 02_{2} \\
\cdot 02_{2}\end{array}$ & $\cdot 06_{7}$ & $\begin{array}{l}92 \cdot 1 \\
92 \cdot 1\end{array}$ & $27^{\circ}{ }_{6}$ & & \\
\hline S H95 & $\mathbf{T}$ & $\begin{array}{r}700 \cdot 37 \\
-778 \cdot 55\end{array}$ & $\begin{array}{c}1600 \\
" 1\end{array}$ & $\begin{array}{l}30 \\
" 1\end{array}$ & $\begin{array}{l}\cdot 33_{0} \\
\cdot 46_{7}\end{array}$ & $\begin{array}{l}\cdot 27_{7} \\
\cdot 36_{3}\end{array}$ & $\begin{array}{l}\cdot 02_{2} \\
\cdot 02_{2}\end{array}$ & $\begin{array}{l}0.00 \\
0.08\end{array}$ & $\begin{array}{l}93 \cdot 5 \\
93 \cdot 2\end{array}$ & $\begin{array}{l}34^{\circ}{ }^{\circ} \\
30^{\circ} 7\end{array}$ & $3^{\circ}$. & $10^{\circ}$ \\
\hline \multirow{4}{*}{$\begin{array}{l}\frac{n}{n} \\
\text { D } \\
\text { ज }\end{array}$} & 0 & $\begin{array}{l}241 \cdot 37 \\
186 \cdot 17\end{array}$ & $\begin{array}{c}1500 \\
\prime \prime\end{array}$ & $\begin{array}{l}40 \\
11\end{array}$ & $\begin{array}{l}\cdot 38_{7} \\
\cdot 34_{7}\end{array}$ & $\begin{array}{l}\cdot 31_{8} \\
\cdot 26_{4}\end{array}$ & - & $\begin{array}{l}\cdot 12_{8} \\
\cdot 10_{7}\end{array}$ & $\begin{array}{l}95 \cdot 9 \\
95 \cdot 9\end{array}$ & $\begin{array}{l}75^{\circ}{ }^{4} \\
80^{\circ} .8\end{array}$ & $5^{\circ} 4$ & 6.9 \\
\hline & $\mathrm{R}$ & $\begin{array}{l}586 \cdot 02 \\
651 \cdot 72\end{array}$ & $\begin{array}{c}1600 \\
" 1\end{array}$ & $\begin{array}{l}30 \\
" 1\end{array}$ & $\begin{array}{l}\cdot 31_{6} \\
\cdot 28_{5}\end{array}$ & $\begin{array}{l}\cdot 24_{9} \\
\cdot 21_{4}\end{array}$ & $\begin{array}{l}\cdot 02_{2} \\
\cdot 02_{2}\end{array}$ & $\cdot 07_{8}$ & $\begin{array}{l}96 \cdot 9 \\
96 \cdot 9\end{array}$ & $24^{\circ}{ }_{6}$ & $4 \cdot{ }_{2}$ & $18^{\circ} \circ$ \\
\hline & $\mathrm{R}$ & $\begin{array}{l}576 \cdot 86 \\
658 \cdot 20 \\
592 \cdot 48\end{array}$ & $\begin{array}{c}1600 \\
" 1 \\
"\end{array}$ & $\begin{array}{l}30 \\
" 1 \\
" 1\end{array}$ & $\begin{array}{l}\cdot 40_{9} \\
\cdot 37_{8} \\
\cdot 32_{5}\end{array}$ & $\begin{array}{l}\cdot 32_{8} \\
\cdot 30_{3} \\
\cdot 25_{8}\end{array}$ & $\begin{array}{l}\cdot 02_{2} \\
\cdot 02_{2} \\
\cdot 02_{2}\end{array}$ & $\begin{array}{l}\cdot 10_{1} \\
\cdot 06_{4} \\
\cdot 02_{7}\end{array}$ & $\begin{array}{l}93 \cdot 2 \\
93 \cdot 2 \\
93.2\end{array}$ & $\begin{array}{l}33^{\circ}{ }^{4} \\
30^{\circ} 7 \\
32 \cdot{ }_{2}\end{array}$ & $2 \cdot 7$ & $8 \cdot 4$ \\
\hline & $\mathrm{T}$ & $\begin{array}{l}516 \cdot 21 \\
489 \cdot 28\end{array}$ & $\begin{array}{l}1600 \\
" 1\end{array}$ & $\begin{array}{l}30 \\
" 1\end{array}$ & $\begin{array}{l}\cdot 59_{3} \\
\cdot 35_{5}\end{array}$ & $\begin{array}{l}\cdot 45_{5} \\
\cdot 31_{0}\end{array}$ & $\begin{array}{l}\cdot 02_{2} \\
\cdot 02_{2}\end{array}$ & $\begin{array}{l}\cdot 17_{8} \\
\cdot 05_{6}\end{array}$ & $\begin{array}{l}93 \cdot 0 \\
93 \cdot 2\end{array}$ & $\begin{array}{l}46^{\circ} \circ \\
44^{\circ}\end{array}$ & $1 \cdot 8$ & $4^{\circ} 0$ \\
\hline
\end{tabular}

$\mathrm{O}$ : Oxidizing $\mathrm{R}$ : Reducing $\mathrm{T}$ : Tapping 


\section{b) 㸮析值の再現性}

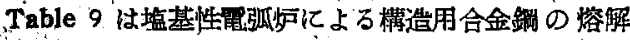

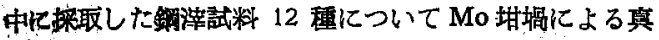

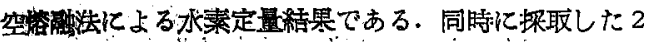
〜3個の試料を分析し，分析偪の偏差之平场值に対する

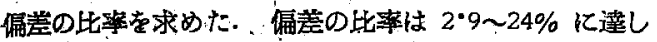
分析の精度はまだ满足でない，Mo，炉惊温排気がでる ないから空值が比皎的大なるととと，試料科取量が小な

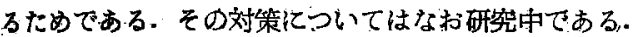
こてに注目すべきは，てのような分析誤羔にすかかわら

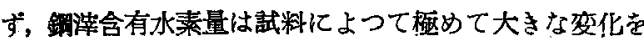
示していることである。

\section{VII. 結 論}

鎆㳯含有水素を定量する目的にて $1200^{\circ} \mathrm{C}$ までの真空

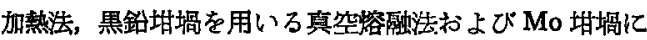
よる真空熔融法を武みた。抽度気体の定量にはこの目的 のために熱伝渞度式水素計を武作し所望の精度が得られ だ.得られた知見を列記するとつきのとおりである。

1）銅㐿含有水素を真空加熱して抽田するためには，

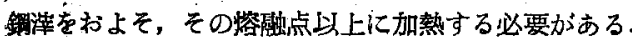

2) 黒鈶坩堝を用いた鋼の真空熔融装置によつて武料 を真空加熱すると，試料より発生する $\mathrm{H}_{2} \mathrm{O}$ は定量的伔 $\mathrm{H}_{2}$ として抽出される。

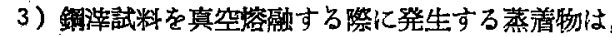
試料の水素分析の障害となる.Sn はこの作用を軽減す 3:

4) Mo 块堝を用いると前部の分析障害は著しく埾减 される. 試数投入後 $100 \mathrm{mn}$ は分析障害作用を無視され 3.

5) $\mathrm{Mo}$ 坩堝を用いるとき $\mathrm{H}_{2} \mathrm{O}$ を $\mathrm{H}_{2}$ に変換するた

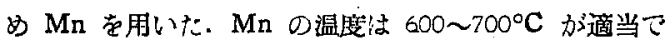
ある。

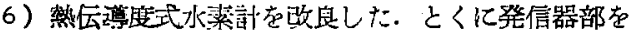

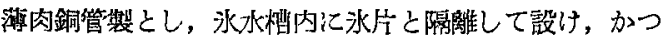
睍汼装置によつて冷水を流動せしめた。これによつて指 示の応答の迅速性と再現性およご安定性は著しく向上し t.

7）試料の探取するび取扱法を定め分析值の再現性を

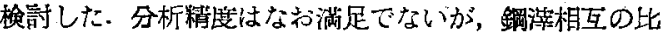
较认は使用可能である。

本研究は村上武次郎先生の御愁篤な御指道の下に, 大 河原社层，王置研究部辰，石原慜鋼部長，佐々木技術部 長，森脇研究課辰备位の御指尊によつて行われたもので ある.実験武料は宗宫狞行先生の御好意によつた。こて

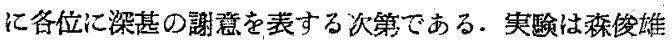
君の多大の助うに負うもので併せて謝意を表する。

（昭和 31 年 3 月寄稿）

女。献

1) 沢 繁樹：鉄之铜，41 (1955) 1166

2) " : 鉄と䠒, 41 (1955) 416

3) P. Herasymenko \& P. Dombrowski: Arch Eisenhuttenwesen 14 (1940) 109

4) 小林位三郎：鉄々䠞，24 (1938) 227

5）日本学術振舆会：特䅀眮の装造に関する破究 V

6) H. Wentrup, H. Fucke u. O. Rief: Stahl u Eisen 69 (1949) 117

7) 沢 繁樹：鉄と銓， 88 (1952) 1026

8) " : 鉄之缺, 38 (1952) 567

9) S. Aoyama \& Y. Oka Sci Rep. Tohoku Imp. Univ 22 (1933) IV 824 